УДК 378.046-021.66:005.95-051

\title{
ОЛЕНА ЖДАНОВА-НЕДІЛЬКО
}

Полтавський національний педагогічний університет імені В. Г. Короленка

\section{ВИКОРИСТАННЯ ОСОБИСТІСНО-РОЗВИВАЛЬНОГО ПОТЕНЦІАЛУ НАВЧАЛЬНОГО ПРОЦЕСУ В МАГІСТРАТУРІ ПРИ ПІДГОТОВЦІ УПРАВЛІНЦЯ}

Розглядаються особливості навчального процесу в магістратурі з позицій особистісного підходу. Аналізується специфіка організації різних форм навчальної роботи як засобу розвитку професійно значущих особистісних якостей майбутнього менеджера, формування в нього здатності до конструктивної взаємодії в управлінській діяльності.

Ключові слова: магістратура, магістрант, майбутній менеджер, особистісний підхід, наукові дослідження студентів, варіативна складова навчання

Актуальність проблеми. Науково-методичне забезпечення навчального процесу в магістратурі $\epsilon$ на сьогодні полем постійного викладацького пошуку, що передбачає чимало інноваційних трансформацій у вищій школі. Адже, як зазначено в Законі «Про вищу освіту» (2014), другий (магістерський) рівень вищої освіти «передбачає здобуття особою поглиблених теоретичних та/або практичних знань, умінь, навичок за обраною спеціальністю (чи спеціалізацією), загальних засад методології наукової та/або професійної діяльності, інших компетентностей, достатніх для ефективного виконання завдань інноваційного характеру відповідного рівня професійної діяльності».

Можливість забезпечити належну підготовку майбутнього магістра передбачає наявність у 3 В0 відповідним чином організованого освітнього середовища, центром якого виступає дидактичний процес втілення провідних функцій закладу, інструмент досягнення в ньому високого професійно-підготовчого результату, що створює його імідж і забезпечує конкурентоспроможність на ринку освітніх послуг. Проте за успішністю освітнього результату завжди стоїть ефективна взаємодія того, хто навчає, i того, хто навчається, спрямована на розвиток можливостей останнього засобами освітньої і самоосвітньої діяльності.

Аналіз досліджень і публікацій. Підготовка магістра в стінах українських 3ВО триває близько двох десятиліть, упродовж яких з'явилося чимало напрацювань вітчизняних дослідників, присвячених цій проблемі (С. Вітвицька, Л. Герасименко, І. Дем'янюк, О. Дубасенюк, О. Ковальчук, Ю. Лянной, О. Макаренко, Н. Мачинська, I. Руснак, О.Федій та ін.). Особливо цікавим уявляється доробок, присвячений підготовці магістрів - майбутніх менеджерів, і зокрема - в освітній галузі (В.Берека, Н. Бєляєва, М. Гриньова, Г. Єльникова, О. Коберник, Ю. Тимцуник та ін.), де управлінська діяльність характеризується багаторівневістю цілей, зорієнтованістю на управління педагогічним колективом, який, у свою чергу, теж виступає суб'єктом управління, як і кожний його член - зокрема і у складі цієї професійної спільноти, поєднаної спорідненими цілями і завданнями.

У роботах вітчизняних учених підготовка до професійної управлінської діяльності зазвичай висвітлюється як формування здатності організовувати продуктивну, чітко зорієнтовану на досягнення певної мети взаємодію вже в процесі навчання при виконанні різних типів завдань у аудиторній та позааудиторній роботі. Однак методичний пошук у цьому напрямі перебуває в перманентно активному стані через оновлення підходів як до цілей управлінської діяльності, так і її змісту, засобів, прийомів, інформаційно-комунікативної специфіки тощо.

Водночас, стабілізація уявлень про сутність освітньо-кваліфікаційного рівня «магістр» та його специфіку з точки зору професійних функцій дозволяє нині більш системно розглядати магістратуру як творче освітнє середовище з визначеними завданнями особистісно-розвивального характеру. Тож мета нашої статті - проаналізувати відомі і окреслити бажані шляхи впливу на особистість майбутнього магістра, зокрема - фахівця в галузі управлінської діяльності.

Виклад основного матеріалу. Середовище підготовки фахівців у магістратурі 3 перших років запровадження відповідного освітнього рівня в Україні набуло ознак, що успішно сприяли розвитку особистості студента як людини з інноваційним мисленням, здатної до креативних рішень у нестандартних умовах. А отже, організація навчання в магістратурі сучасної української вищої школи передбачає вивчення і застосування ії особистісно-розвивальних можливостей.

Аналізуючи навчальний процес у магістратурі, вважаємо за необхідне закцентувати низку його особливостей, що мають бути враховані як окремими викладачами, так і всім викладацьким колективом.

Вступ випускників бакалаврату до магістратури та подальше компонування академічних груп дозволяє отримати навчальні спільноти, які, з одного боку, в переважній більшості не є для випускаючої кафедри абсолютно новими за особистим складом, як це буває на 1 курсі бакалаврату, а з іншого - їхній кількісний і якісний склад є цілком своєрідним. Не слід вважати, що початок занять у магістратурі ніяким 
чином не задіює адаптаційні процеси, навіть якщо все навчання відбувається в межах одного факультету. Незначні, на перший погляд, зміни в складі можуть дати несподіваний педагогічний і комунікативний ефект, специфіку якого варто розпізнати вже в перший місяць навчання. Водночас, практика показує, що магістерські групи в більшості своїй відрізняються більш зрілим ставленням до подальшої професійної діяльності. Певна частина «випадкових» людей залишила навчання, в результаті чого підвищується загальний рівень зацікавленості щодо дидактичного процесу, активна включеність до нього розглядається як обов'язкова норма, а особистісна дистанція студентів з викладачем має тенденцію до скорочення. Як зазначає О. Макаренко, на цьому освітньому рівні, зазвичай, «існує ефективна систематизована колаборативна взаємодія між усіма суб'єктами підготовки, що позитивно впливає на функціонування мотиваційної, когнітивної, практично-діяльнісної та науково-дослідницької складових магістерської підготовки» (Макаренко, 2017, с. 83).

Мотиваційні аспекти успішної підготовки до професійної діяльності на час вступу до магістратури зазнають повторної актуалізації і у процесі міжособистісної взаємодії, зазвичай, стимулюються за рахунок обміну досвідом, здобутим у ході навчальних практик, власної роботи в установах та організаціях, більш щільної прив'язки навчального процесу до професійної сфери. Останньому, зокрема, сприяють кваліфікаційні магістерські роботи, що розуміються не лише як належним чином оформлені результати навчальних досліджень: вони стають для кожного магістранта одним із потужних стрижнів самоорганізації впродовж усього терміну навчання, ланкою зв'язку між навчальними дисциплінами, які завдяки цьому все більш усвідомлюються як логічно вибудувана система складників професійної підготовки, інтегруючим чинником при проходженні виробничої практики, підгрунтям для участі в наукових конференціях, професійних форумах.

Більшістю дослідників магістерська робота розглядається як підсумок всього процесу навчання, оскільки в ній виявляється «рівень теоретичної загальнонаукової та професійної підготовки автора, його вміння застосовувати одержані знання під час вирішення професійно-орієнтованих завдань та здатність до самостійної професійної діяльності» (Безверхнюк, Руда \& Сенча, 2014, с. 7). Водночас спорідненість теми й змісту дослідження з проблематикою, відображеною в змісті навчальних дисциплін, сприяє тому, що індивідуальна дослідницька робота студента може органічно вплітатися в навчальну роботу групи чи потоку, презентуватися у вигляді логічно завершених фрагментів, дозволяючи авторові демонструвати свої досягнення і водночас створюючи умови для посилення його дослідницької мотивації.

Поетапну презентацію дослідницької роботи розглядаємо як важливий складник навчального процесу ще й з тих міркувань, що вона є по-своєму унікальним навчальним засобом по відношенню до інших студентів. Завдяки його використанню відбувається обмін ідеями, зародження нових бачень тієї чи іншої професійної проблеми.

У практиці підготовки магістрів з управління навчальними закладами, управління проектами, управління інноваційною діяльністю нами неодноразово застосовувався дидактичний прийом, що позиціонувався як діяльність навчально-дослідницької групи. Працюючи з кількома магістрантами, ми намагалися в такий спосіб сформулювати теми їхніх кваліфікаційних досліджень, щоб вони різнобічно розкривали різноманітні напрями професійної діяльності управлінця, торкалися його актуальних функцій тощо. Утворювався дослідницький колектив, що взаємодіяв і в навчальний, і в позанавчальний час; його робота планувалася посеместрово, у відповідності з навчальними планами, у співробітництві з іншими викладачами кафедри, які також могли пропонувати дослідникам розробку певних фрагментів занять, електронних презентацій, координувати роботу кількох дослідників при вивченні навчальної теми чи змістового модуля.

Зараз, коли навчання в магістратурі охоплює понад один навчальний рік, залучення магістрантів до організації навчального процесу набуває дедалі різноманітніших форм. Так, упродовж першого семестру магістранти старшого курсу залучаються до роботи з тими, хто щойно прийнятий на навчання, як групові, а часом і індивідуальні куратори, консультанти з певних дисциплін, помічники у виборі бази виробничої практики, проведення досліджень тощо. Вже традиційною стала допомога викладачеві в процесі перевірки індивідуальних завдань, самостійної роботи тощо. Це не є істотною інновацією для вищої освіти: так, наприклад, відомо, що для американських 3ВО характерне залучення студентів-старшокурсників до перевірки контрольних робіт, що їх пишуть молодші колеги, інших форм допомоги педагогові (Ліневич \&Мирончук, 2014). Проте в умовах вітчизняної вищої школи цей спосіб делегування окремих викладацьких повноважень ще потребує методичного опрацювання і узагальнення позитивного досвіду. Вважаємо, що за певних умов такі форми роботи могли б розглядатися як елементи професійного стажування, завдяки яким у майбутніх магістрів відпрацьовувалися б навички дидактичної комунікації, етичні засади навчальнооцінної діяльності в квазіпрофесійному колективі, а також, що важливо для кадрового забезпечення сучасних 3В0, була б змога з'ясувати можливість для випускника оптимального поєднання дослідницьких і дидактичних умінь і зробити практику рекомендації кращих випускників до аспірантури більш педагогічно зорієнтованою. Особистісний підхід до підготовки майбутнього фахівця, що набув значного поширення у вітчизняній вищій школі, має свої позитивні моменти, що можуть бути втрачені, якщо педагогічний складник діяльності викладача зазнає значного упослідження. Він має переглядатися, переоцінюватися, проте підміна його виключно науково-дослідницькою складовою може завдати істотної шкоди вітчизняній вищій школі на сучасному етапі. Адже «саме особистість із її характерними рисами, власною активністю, якісними змінами у процесі розвитку впливає на успішність професійного становлення... Професійне 
навчання необхідно будувати в такий спосіб, щоб створити можливість підтримувати розвиток особистості, забезпечуючи стимулювання її власної активності у поведінці та професійному становленні й реалізації» (Колісниченко, 2004, с. 8).

Закордонна практика підготовки магістра, що, з одного боку, є більш усталеною, а з іншого - достатньо динамічною і адаптованою до сучасних умов, налаштовує на досить критичний відбір викладацького складу, проте не заперечує значущості для педагога вищої школи особистісно-формувальних аспектів діяльності. Так, Н. Мачинська (2013), посилаючись на розроблені Національною Радою 3 акредитації педагогічної освіти США (National Council for Accreditation of Teacher Education) професійні стандарти для педагогів різної кваліфікації, зокрема для викладачів вищої школи, характеризує три кваліфікаційні рівні (неприйнятний, прийнятний, бажаний) у таких сферах діяльності викладача вищого навчального закладу: викладацький склад, модель вкладання, модель науково-дослідної роботи, модель суспільної роботи, співпраця, загальне оцінювання професійної діяльності, професійний розвиток.

Не торкаючись тут найнижчого рівня, відзначимо, що прийнятною окреслена ситуація, коли викладачі володіють глибоким змістом власного предмета; викладання відображає концепції сучасних досліджень у педагогічній галузі; викладачі використовують різноманітні методи та технології викладання; здійснюється систематичне оцінювання навчальних досягнень студентів; стиль викладання заохочує студентів до рефлексії, критичного мислення, вирішення різноманітних навчальних проблем і ситуацій. Врешті, бажаний рівень викладання передбачає, що викладачі володіють поглибленим змістом предмета, який викладають; уміло поєднують функції викладача та вченого, демонструючи інтелектуальну зацікавленість у проблемних питаннях; застосовуються широкий діапазон методів і технологій викладання, індивідуальний підхід до студентів; використовуються різноманітні форми та методи оцінювання, враховується їхня ефективність у кожному випадку; більшість із викладачів визнані колегами як видатні науковці та педагоги (Мачинська, 2013, с. 181).

Звертаємо увагу на помітну в цьому викладі тенденцію: характеристики педагогічної майстерності викладача виступають підгрунтям досягнення ним так званого бажаного (найвищого) рівня, де відбувається інтеграція дидактичного і науково-дослідницького рівня. При цьому, до сказаного нами вище, акцентується і необхідність заохочення студентів «до рефлексії, критичного мислення, вирішення різноманітних навчальних проблем і ситуацій», що, на наш погляд, здатна успішно вирішуватися саме при залученні до роботи з молодшими колегами, елементи якої ми практикуємо і обстоюємо.

Окрім аудиторної роботи, значну вагу для підготовки магістра має його залучення й до позавишівських заходів, що здійснюються не лише у професійній, але часом і в громадській, суспільнополітичній сфері. Величезний обсяг інновацій, що торкнувся життя сучасного українського суспільства, неминуче торкається не лише особистого, а й професійно-діяльнісного аспекту життя кожної людини. Завдання викладача - вчасно відстежувати події, заходи, до проведення яких можуть бути причетні магістранти, і при цьому відвідування цих заходів, участь у їхньому проведенні повинні бути не лише чітко аргументовані в контексті професійної підготовки, а й належним чином інструментовані. Попередня підготовка повинна бути достатньо тривалою, анонсованою, за можливості - включати елементи функціонального розподілу. Доречно, аби з числа магістрантів призначались відповідальні за участь у заході, які заздалегідь представляли історію його організації, сенс і мету проведення, місце в стратегії і тактиці здійснення певних змін у професійній чи загально-суспільній сфері. Таким чином студенти розширюють уявлення про різні форми публічної діяльності, осягають її внутрішню і зовнішню філософію, коригують власні бачення і опановують різні форми активності при вирішенні значущих для життя нашої країни проблем.

3 розширенням поля використання в навчальному процесі електронних пристроїв та ресурсів викладач отримує можливість напрацьовувати широку методичну базу, засновану на відповідних способах здобуття і фіксації інформації. Так, провертаючись до наведеного вище прикладу, він може, зокрема, не вдаватися без зайвої потреби до розширеного усного обговорення та аналізу побаченого, маючи змогу отримати письмові відповіді на запропоновані ключові питання; створити аналітичну групу, що опрацювала б ці відгуки і презентувала найбільш показові і важливі точки зору, спонукала до обговорення найважливіших проблемних моментів тощо. Для викладача ж цей матеріал є безцінним не тільки в роботі 3 окремими студентами та академічними групами, а й для створення методичних матеріалів на подальші роки, відстеження тенденцій, формулювання актуальних дослідницьких тем і таке інше.

Нами практикується залучення студентів до створення таких матеріально мало затратних дидактичних об’єктів, як описи професійних середовищ різного типу, конфліктних ситуацій, що можуть виникати в управлінській діяльності, добірок інформації з певної проблеми, відео хрестоматій, що розкривають актуальні проблеми як власне професійної діяльності, так і особистісного становлення майбутнього чи діючого менеджера. Низька матеріальна затратність при цьому не виключає значних часових затрат викладача, який формувати цю інформаційну базу самотужки просто не в змозі, хоча їі впорядкування, методичне оснащення тощо потребує чималих зусиль.

Водночас, реалізація окреслених вище форм роботи має розглядатися як допустима у своїй варіативності та методичній доцільності і внормативована належним чином, оскільки їхнє застосування часто зумовлене ситуативними чинниками і не може бути у вичерпному вигляді передбачене навчальними програмами. Тож назріло питання елективного складника програми, що може включати види діяльності, 
довільно обрані викладачем, але достатньо аргументовані відповідно до прогнозованих навчальних результатів.

Висновки та перспективи подальших досліджень. Таким чином, навчальний процес у магістратурі сучасного 3В0, і насамперед - при підготовці кваліфікованих управлінських кадрів, передбачає максимальну активізацію студента як суб'єкта здійснення навчальної, дослідницької, а також організаційно-педагогічної діяльності, що дає йому змогу цілеспрямовано вдосконалювати особистіснопрофесійні якості, необхідні для конструктивної взаємодії. Разом із тим, удосконалення процесу викладання, наближення змісту навчання до реальних потреб студентства ставить на потребу більш детальне дослідження застосовуваних форм і методів особистісно зорієнтованого освітнього процесу 3 огляду на реалії сучасності.

\section{Список використаних джерел}

Безверхнюк, Т. М., Руда І.В., Сенча I. А. (2014) Магістерська робота: написання, оформлення, захист: навч.метод. посібник для слухачів денної та заочної форми навчання за спеціальністю 8.18010013 «Управління проектами». - Одеса : ОРІДУ НАДУ.

Колесниченко, Л.А.(2004). Психологічні особливості саморегуляиії у професійній діяльності менеджерів (Автореф. дис.. канд.. пс. наук 19.00.07 - педагогічна та вікова психологія). - Київ, ЦІППО НАН України.

Ліневич, А., Мирончук, Н. (2014) Досвід підготовки магістрів за кордоном (США, Англія). Модернізація вищої освіти в Украӥні та за кордоном : збірник наукових праџъ. Вітвицька, С.С., Мирончук, Н.М. (Ред.) (213-216). Житомир: Вид-во ЖДУ ім. І. Франка.

Макаренко, О. Л. (2017) Підготовка магістрів з освітніх вимірювань у педагогічному університеті (Дис. ... канд.. пед..наук 13.00.04 - теорія і методика професійної освіти). - Київ, НПУ ім. М. П. Драгоманова.

Мачинська, Н. І. (2013) Педагогічна освіта магістрантів вищих навчальних закладів непедагогічного профілю: монографія. Сисоєва, С.А. (Ред.) Львів: ЛьвДУВС.

\section{References}

Bezverkhniuk, T. M., Ruda I.V., Sencha I. A. (2014) Mahisterska robota: napysannia, oformlennia, zakhyst: navch.metod. posibnyk dlia slukhachiv dennoi ta zaochnoi formy navchannia za spetsialnistiu 8.18010013 «Upravlinnia proektamy». - Odesa : ORIDU NADU.

Kolesnychenko, L.A.(2004). Psykholohichni osoblyvosti samorehuliatsii u profesiinii diialnosti menedzheriv (Avtoref. dys.. kand.. ps. nauk 19.00.07 - pedahohichna ta vikova psykholohiia). - Kyiv, TsIPPO NAN Ukrainy.

Linevych, A., Myronchuk, N. (2014) Dosvid pidhotovky mahistriv za kordonom (SShA, Anhliia). Modernizatsiia vyshchoi osvity v Ukraini ta za kordonom : zbirnyk naukovykh prats. Vitvytska, S.S., Myronchuk, N.M. (Red.) (213216). Zhytomyr: Vyd-vo ZhDU im. I. Franka.

Makarenko, O. L. (2017) Pidhotovka mahistriv z osvitnikh vymiriuvan u pedahohichnomu universyteti (Dys. ... kand.. ped..nauk 13.00.04 - teoriia i metodyka profesiinoi osvity). - Kyiv, NPU im. M. P. Drahomanova.

Machynska, N. I. (2013) Pedahohichna osvita mahistrantiv vyshchykh navchalnykh zakladiv nepedahohichnoho profiliu: monohrafiia. Sysoieva, S.A. (Red.) Lviv: LvDUVS.

\section{ZHDANOVA-NEDILKO 0.}

Poltava V. G. Korolenko national pedagogical University, Ukraine

\section{USING THE PERSONALITY-DEVELOPING POTENTIAL OF THE EDUCATIONAL PROCESS IN THE MAGISTRACY OF THE PREPARATION OF THE MANAGER}

The peculiarities of the educational process in the magistracy from the standpoint of a personality approach are considered. The specifics of organization of various forms of educational work as a means of development of professionally significant personal qualities of the future manager, forming in him the ability to constructive interaction in management activity are analyzed.

It is proved that the educational process in the magistracy of modern High school, and first of all - in the preparation of skilled management personnel, involves maximal activation of the student as a subject of educational, research, as well as organizational and pedagogical activity, which enables him to purposefully improve personal and professional qualities , necessary for constructive interaction. Present opportunities of classroom and non-classroom work in shaping the personality of the future manager. It is grounded that the improvement of the teaching process, the approach of the content of teaching to the real needs of students, calls for a more detailed study of the applied forms and methods of a personally oriented educational process in view of the realities of the present.

Key words: magistracy, master's degree, future manager, personal approach, student research, variational component of teaching

Стаття надійшла до редакції 22.09. 2018 р. 